National Matters 
This page intentionally left blank 


\section{National Matters}

M A T E R I A L T Y, C U L T UR E, A N D

N A T I O N A L I S M

Edited by Geneviève Zubrzycki

S T A N F OR D U N I V ER S T Y PRES S

S T A N F OR D, C A L I F O R N I A 
Stanford University Press

Stanford, California

(C) 2017 by the Board of Trustees of the Leland Stanford Junior University.

All rights reserved.

No part of this book may be reproduced or transmitted in any form or by any means, electronic or mechanical, including photocopying and recording, or in any information storage or retrieval system without the prior written permission of Stanford University Press.

Printed in the United States of America on acid-free, archival-quality paper

Library of Congress Cataloging-in-Publication Data

Names: Zubrzycki, Geneviève, editor.

Title: National matters : materiality, culture, and nationalism / edited by Geneviève Zubrzycki.

Other titles: National matters (Stanford, Calif.)

Description: Stanford, California : Stanford University Press, 2017. | Includes bibliographical references and index.

Identifiers: LCCN 2016045538 (print) | LCCN 2016046511 (ebook) | ISBN 9781503601697

(cloth : alk. paper) | ISBN 9781503602533 (pbk. : alk. paper) | ISBN 9781503602762 (ebook)

Subjects: LCSH: Nationalism. | Material culture-Political aspects. | Politics and culture.

Classification: LCC JC311.N2917 2017 (print) | LCC JC311 (ebook) | DDC 320.54-dc23

LC record available at https://lccn.loc.gov/2016045538 